\title{
Hubungan Defisiensi Besi dengan Perilaku Anak Usia Sekolah di Kota Palembang
}

\author{
Desti Handayani, ${ }^{*}$ Rismarini, ${ }^{*}$ Yudianita Kesuma, ${ }^{*}$ Rini Purnamasari, ${ }^{*}$ Syarif Husin $* *$ \\ * Departemen Ilmu Kesehatan Anak, ${ }^{* *}$ Unit Penelitian Kedokteran Kesehatan FK Universitas Sriwijaya/ \\ RS Moh. Hoesin, Palembang
}

\begin{abstract}
Latar belakang. Prevalensi defisiensi besi anak usia sekolah di Indonesia sebesar $47,2 \%$. Defisiensi besi menyebabkan perkembangan dan fungsi saraf terganggu, termasuk timbulnya masalah perilaku. Belum ada penelitian yang menilai hubungan defisiensi besi dan masalah perilaku anak usia sekolah di Palembang. Tujuan. Menganalisis hubungan defisiensi besi dengan masalah perilaku anak usia sekolah di Palembang. Metode. Desain penelitian deskriptif analitik dengan pendekatan cross sectional. Subjek penelitian adalah anak Sekolah Dasar (SD) usia 6-12 tahun di Palembang yang dipilih dengan multi stage random sampling pada bulan April sampai Juni 2013. Pada semua subjek penelitian dilakukan pemeriksaan fisis, laboratorium (hemoglobin, besi serum, dan saturasi transferin), dan penilaian perilaku menggunakan Pediatric Symptom Checklist (PSC) 17. Perbedaan kejadian masalah perilaku antara subjek dengan dan tanpa defisiensi besi dianalisis dengan uji kai kuadrat. Faktor risiko lain yang berpengaruh dianalisis dengan regresi logistik. Hasil. Dari 125 subjek yang terpilih didapatkan prevalensi defisiensi besi $26,6 \%$, anemia defisiensi besi $25 \%$, dan kejadian masalah perilaku 29\%. Dari 33 subjek dengan defisiensi besi terdapat 20 yang memiliki masalah perilaku, sedangkan dari 81 subjek tanpa defisiensi besi terdapat 14 dengan masalah perilaku (uji kai kuadrat, $\mathrm{p}=0,001$; OR 7,363; IK95\%:2,978-18,203). Pada penilaian tipe perilaku, terdapat hubungan bermakna antara defisiensi besi dengan perilaku internalisasi ( $p=0,001$, OR 7,604; IK95\%:2,462-18,363). Ditemukan faktor yang paling berpengaruh terhadap perilaku, melalui analisis regresi logistik, yaitu defisiensi besi ( $\mathrm{p}=0,001$; adjusted OR 6,901; IK95\%:2,816-16,914).

Kesimpulan. Defisiensi besi merupakan faktor risiko terjadinya masalah perilaku, terutama perilaku internalisasi. Sari Pediatri 2015;16(5):307-14.
\end{abstract}

Kata kunci: defisiensi besi, masalah perilaku, usia sekolah

\footnotetext{
Alamat korespondensi:

Dr. Desti Handayani. Departemen Ilmu Kesehatan Anak FK Universitas Sriwijaya/RS Mohammad Hoesin Palembang Jl. Jenderal Sudirman Km 3,5 Palembang 30126. Telp: 08127842012 . E-mail: desti_handayani_dr@ yahoo.co.id
}

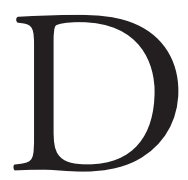

efisiensi besi merupakan salah satu masalah defisiensi nutrisi terbesar. Di dunia diperkirakan dua milyar orang menderita defisiensi besi. ${ }^{1}$ Defisiensi Besi terjadi apabila kebutuhan besi di dalam tubuh tidak terpenuhi dari makanan yang dikonsumsi atau 
kebutuhan besi meningkat sehingga terjadi kekurangan cadangan besi. Jika keseimbangan negatif ini terus berlangsung lama, ketersediaan besi dalam tubuh akan dikompensasi sehingga terjadi eritropoesis defisiensi besi. Lima belas persen penduduk dunia diperkirakan menderita anemia defisiensi besi. ${ }^{2}$

Penelitian oleh IDAI, pada 1000 anak sekolah di 11 provinsi di Indonesia, menunjukkan prevalensi anemia 20\%-25\% dan perkiraan jumlah anak yang mengalami defisiensi besi tanpa anemia lebih banyak lagi. ${ }^{3}$ Menurut Riset Kesehatan Dasar (Riskesdas) 2007, prevalensi anemia Propinsi Sumatera Selatan $16,5 \%$ dan $70,1 \%$ di antaranya merupakan anemia hipokrom mikrositer. Di Indonesia, pada anak usia sekolah, prevalensi defisiensi besi $47,2 \%{ }^{4}$

Defisiensi besi dapat menyebabkan beberapa efek biologis yang berperan penting dalam perkembangan dan fungsi saraf. ${ }^{5}$ Beberapa penelitian terakhir menunjukkan defisiensi besi mengakibatkan perubahan fungsi pada otak anak, baik fungsi kognitif ataupun nonkognitif. Pada sistem saraf, defisiensi besi mengakibatkan gangguan metabolisme neurotransmiter, penurunan myelinisasi, dan perubahan metabolisme otak. Perubahan ini melibatkan beberapa jalur biokimia, seperti dopamin, serotonin, dan reseptor D2. Perubahan ini akan mengakibatkan penurunan fungsi kognitif dan adanya perilaku abnormal. ${ }^{6}$ Penelitian Fatimah dkk, ${ }^{7}$ di Palembang, menunjukkan bahwa kadar IQ anak dengan defisiensi besi lebih rendah 2,83 kali dibandingkan anak yang tidak defisiensi besi. Sebaliknya, terapi besi menimbulkan perubahan yang signifikan pada fungsi kognisi dan pencapaian hasil pendidikan dibandingkan anak yang hanya mendapatkan plasebo. ${ }^{8,9}$

Lebih dari tiga dekade terakhir banyak dilaporkan penelitian mengenai defisiensi besi dan perilaku. Anak dengan defisiensi besi memiliki kecenderungan memiliki gangguan perilaku, baik internalisasi ataupun eksternalisasi dibandingkan anak tanpa defisiensi besi. ${ }^{10-12}$ Penelitian mengenai hubungan antara defisiensi besi dan perilaku telah banyak dilakukan, tetapi penelitian pada anak usia sekolah belum banyak dilaporkan dan penggolongan tipe masalah perilaku dan faktor perancu yang dapat menimbulkan masalah perilaku belum diuraikan dengan jelas. Tujuan dari penelitian ini menganalisis hubungan defisiensi besi dengan perilaku anak sekolah di Kota Palembang.

\section{Metode}

Penelitian deskriptif analitik dengan pendekatan cross sectional yang dilakukan dari April sampai dengan Juni 2013. Kriteria inklusi adalah anak Sekolah Dasar (SD) terpilih yang berusia 6-12 tahun saat penelitian dan orang tua bersedia anaknya diikutsertakan dalam penelitian. Kriteria eksklusi adalah anak yang menderita kelainan neurologis, defisit sensorik (tuli), retardasi mental, autisme, ADHD (attention deficit hyperactivity disorder), penyakit kronis, dan status gizi buruk.

Teknik sampling yang digunakan adalah multistage random sampling. Wilayah Kota Palembang dibagi menjadi dua wilayah, yaitu Seberang Ulu dan Seberang Ilir. Wilayah Seberang Ilir diambil tiga kecamatan karena memiliki kepadatan penduduk lebih banyak. Sementara itu, wilayah Seberang Ulu diambil dua kecamatan. Setiap kecamatan dipilih dua kelurahan secara acak sederhana dan dari tiap kelurahan dipilih satu SD. Jumlah subjek penelitian adalah 125 anak dari 10 SD yang terpilih.

Semua murid SD yang terpilih dilakukan pencatatan meliputi karakteristik umum, riwayat tumbuh kembang, riwayat kehamilan ibu, riwayat kelahiran, riwayat imunisasi, dan riwayat penyakit. Pemeriksaan fisik dilakukan berupa pengukuran antropometri dan pemeriksaan neurologi. Pemeriksaan laboratorium meliputi hemoglobin dan status besi (serum iron, total iron binding capacityl TIBC dan saturasi transferin). Pengisian formulir PSC-17 dilakukan dengan wawancara langsung ke orang tua subjek penelitian.

Klasifikasi pendidikan ayah dan ibu berdasarkan batasan Badan Pusat Statistik, yaitu $\leq 9$ tahun (SDSMP) sebagai tingkat pendidikan rendah, 10-15 tahun (SMA-D3) sebagai tingkat pendidikan menengah, dan $>15$ tahun (S1-S3) sebagai tingkat pendidikan tinggi. Status ekonomi diukur berdasarkan jumlah pengeluaran keluarga per kapita per bulan menurut upah minimum regional kota Palembang tahun 2011, pengeluaran $<\mathrm{Rp} 1.095 .831,00$ dikategorikan sebagai rendah dan $\geq R p$ 1.095.831,00 dikategorikan sebagai tinggi.

Pediatric Symptom Checklist 17 (PSC-17) merupakan kuesioner yang digunakan untuk melakukan skrining perilaku anak usia 4-18 tahun yang menilai tiga karakteristik perilaku, yaitu internalisasi, eksternalisasi, dan perhatian. Interpretasi PSC-17 adalah sebagai 
berikut, memiliki masalah perilaku jika dari subskala internalisasi skor $\geq 5$, eksternalisasi $\geq 7$, perhatian $\geq 7$ atau jika jumlah ketiga subskala $\geq 15 .{ }^{13}$ Penilaian sifat ayah, ibu, perlakuan kepada anak, dan lingkungan didasarkan atas penilaian subjektif peneliti.

Tahapan defisiensi besi terdiri atas deplesi besi, defisiensi besi, dan anemia defisiensi besi. Penilaian status besi tersebut didasarkan pada saturasi transferin dengan menghitung perbandingan kadar SI dan TIBC. Apabila saturasi transferin 20\%-30\% disebut deplesi besi dan $<20 \%$ disebut defisiensi besi. Dikatakan anemia defisiensi besi apabila terdapat penurunan hemoglobin dan saturasi transferin $<20 \%{ }^{14}$

Kerahasian data subjek dijaga. Pada subjek yang mengalami defisiensi besi diberikan terapi besi dan anak dengan masalah perilaku akan disarankan untuk berkonsultasi ke Klinik Tumbuh Kembang RSMH Palembang. Penelitian ini telah dinyatakan layak etik oleh Komisi Etik Penelitian Kedokteran Universitas Sriwijaya Palembang. Semua data dicatat dan diolah menggunakan perangkat lunak SPSS 16.0. Analisis data defisiensi besi sebagai faktor risiko masalah perilaku menggunakan kai kuadrat. Kekuatan hubungan dinyatakan dalam bentuk OR (Odds Ratio). Tingkat kemaknaan yang digunakan adalah $\mathrm{p}<0,05$. Status besi dan variabel lain yang diperkirakan dapat memengaruhi perilaku, yaitu jenis kelamin, status gizi, pendidikan orang tua, status ekonomi, status perkawinan, pola pengasuhan, sifat orang tua, dan lingkungan dianalisis secara multivariat dengan regresi logistik.

\section{Hasil}

Pemeriksaan laboratorium dilakukan pada 125 subjek, satu sampel darah mengalami hemolisis sehingga hanya 124 subjek yang dianalisis. Subjek penelitian terdiri atas $74(59,7 \%)$ laki-laki dan 50 (40,3\%) perempuan. Rasio laki-laki berbanding perempuan adalah 1,48:1. Usia subjek penelitian terbanyak, $31(25 \%)$, adalah tujuh tahun. Hanya satu orang anak yang memiliki penyakit bawaaan, yaitu duktus arteriosus persisten, selebihnya tidak ditemukan riwayat penyakit atau hanya penyakit infeksi ringan. Setelah dilakukan penilaian antropometri terhadap subjek penelitian didapatkan status gizi baik 91 $(73,4 \%)$ dan gizi kurang $33(26,6 \%)$. Karakteristik subjek tertera pada Tabel 1.
Tabel 1. Karakteristik subjek dan orang tua $(n=124)$

\begin{tabular}{|c|c|c|}
\hline Karakteristik subjek & Jumlah & Persentase \\
\hline \multicolumn{3}{|l|}{ Jenis kelamin } \\
\hline Laki-laki & 74 & 59,7 \\
\hline Perempuan & 50 & 40,3 \\
\hline \multicolumn{3}{|l|}{ Usia (tahun) } \\
\hline 6 & 13 & 10,5 \\
\hline 7 & 31 & 25 \\
\hline 8 & 14 & 11,3 \\
\hline 9 & 9 & 7,3 \\
\hline 10 & 22 & 17,7 \\
\hline 11 & 25 & 20,2 \\
\hline 12 & 10 & 8,1 \\
\hline \multicolumn{3}{|l|}{ Riwayat penyakit dahulu } \\
\hline $\mathrm{DBD}$ & 1 & 0,8 \\
\hline Gastritis & 1 & 0,8 \\
\hline PDA & 1 & 0,8 \\
\hline Tifoid & 7 & 5,6 \\
\hline Tidak ada & 114 & 91,9 \\
\hline \multicolumn{3}{|l|}{ Status gizi } \\
\hline Kurang & 33 & 26,6 \\
\hline Baik & 91 & 73,4 \\
\hline \multicolumn{3}{|l|}{ Pendidikan ayah } \\
\hline Rendah & 63 & 50,8 \\
\hline Menengah & 55 & 44,3 \\
\hline Tinggi & 6 & 4,8 \\
\hline \multicolumn{3}{|l|}{ Pendidikan ibu } \\
\hline Rendah & 56 & 45,2 \\
\hline Menengah & 62 & 50 \\
\hline Tinggi & 6 & 4,8 \\
\hline \multicolumn{3}{|l|}{ Status ekonomi } \\
\hline Rendah & 58 & 46,8 \\
\hline Tinggi & 66 & 53,2 \\
\hline \multicolumn{3}{|l|}{ Status perkawinan } \\
\hline Menikah & 113 & 91,1 \\
\hline Cerai hidup & 4 & 3,2 \\
\hline Cerai mati & 6 & 4,8 \\
\hline \multirow{2}{*}{\multicolumn{3}{|c|}{ Sifat ayah }} \\
\hline & & \\
\hline Pemarah & 39 & 31,4 \\
\hline Penyabar & 50 & 40,3 \\
\hline Pencemas & 1 & 0,8 \\
\hline Biasa & 34 & 27,4 \\
\hline \multicolumn{3}{|l|}{ Sifat ibu } \\
\hline Pemarah & 22 & 17,7 \\
\hline Penyabar & 68 & 54,8 \\
\hline Biasa & 34 & 27,4 \\
\hline \multicolumn{3}{|l|}{ Perlakuan kepada anak } \\
\hline Dimanja & 25 & 20,2 \\
\hline Biasa & 99 & 79,8 \\
\hline \multicolumn{3}{|l|}{ Pengasuh } \\
\hline Orang tua & 114 & 91,9 \\
\hline Orang tua tunggal & 4 & 3,2 \\
\hline Selain orang tua & 6 & 4,8 \\
\hline \multicolumn{3}{|l|}{ Kondisi lingkungan } \\
\hline Baik & 82 & 66,1 \\
\hline Cukup & 42 & 33,9 \\
\hline
\end{tabular}


Hasil pemeriksaan laboratorium terhadap 124 subjek penelitian didapatkan rerata kadar hemoglobin $11,7 \mathrm{~g} / \mathrm{dL}(8,0-13,9) \mathrm{g} / \mathrm{dL}$, serum iron (SI) $107 \mu \mathrm{g} / \mathrm{dL}$ (30-357) $\mu \mathrm{g} / \mathrm{dL}$, TIBC 293,1 $\mu \mathrm{g} / \mathrm{dL}(61-710) \mu \mathrm{g} / \mathrm{dL}$, dan saturasi transferin $47,6 \%(6,1-74,1) \%$. Dari data cadangan besi didapatkan prevalensi status besi normal $65,3 \%$, deplesi besi $8,1 \%$, defisiensi besi $26,6 \%$, dan anemia defisiensi besi $25 \%$.

Penilaian perilaku ditentukan berdasarkan pemeriksaan Pediatric Symptom Checklist 17 (PSC17). Terdapat 36 subjek dengan masalah perilaku, terdiri atas internalisasi 23 , eksternalisasi 5, perhatian 5, internalisasi dan perhatian 2, serta internalisasi dan eksternalisasi 1 subjek. Dari 43 subjek yang mengalami defisiensi besi terdapat 22 dengan masalah perilaku.

Pada 36 subjek dengan masalah perilaku, ternyata 22 mempunyai kadar besi yang rendah (deplesi dan defisiensi besi) dan 14 dengan status besi normal. Pada uji kai kuadrat dtunjukkan adanya hubungan status besi (deplesi dan defisiensi besi) dengan masalah perilaku dengan nilai $\mathrm{p}=0,001$ dan Odds Ratio 5,014 (IK95\%:2,186-11,500).

Ditemukan adanya hubungan yang bermakna antara defisiensi besi dan masalah perilaku $(\mathrm{p}=0,001)$ dengan nilai Odds Ratio 7,363. Ditemukan hubungan yang bermakna antara anemia defisiensi besi dengan masalah perilaku dengan nilai Odds Ratio 7,577 $(\mathrm{p}=0,001)$. Sementara itu, dengan uji fisher, deplesi besi dan masalah perilaku tidak dijumpai hubungan yang bermakna.

Masalah perilaku yang diidentifikasi terdiri atas masalah perilaku internalisasi, eksternalisasi, perhatian, dan campuran. Pada Tabel 3 tertera hubungan status besi dan perilaku internalisasi.

Dengan uji kai kuadrat ditemukan adanya hubungan yang bermakna antara defisiensi besi dan masalah perilaku internalisasi $(\mathrm{p}=0,001)$ dengan nilai Odds Ratio 7,604 dan juga terdapat hubungan yang bermakna antara anemia defisiensi besi dan masalah perilaku internalisasi subjek penelitian $(\mathrm{p}=0,001)$

Tabel 2. Hubungan tahapan status besi dengan masalah perilaku

\begin{tabular}{|c|c|c|c|c|c|c|c|}
\hline \multirow[t]{2}{*}{ Status besi } & \multicolumn{4}{|c|}{ Masalah perilaku } & \multirow[t]{2}{*}{ Jumlah } & \multirow{2}{*}{$\begin{array}{c}\text { OR } \\
(\mathrm{IK} 95 \%)\end{array}$} & \multirow[t]{2}{*}{$\mathrm{p}$} \\
\hline & $\mathrm{Ya}$ & $\%$ & Tidak & $\%$ & & & \\
\hline Deplesi besi & & & & & & & $0,481^{*}$ \\
\hline Ya & 1 & 1,09 & 9 & 9,90 & 10 & $0,532(0,062-4,541)$ & \\
\hline Tidak & 14 & 15,38 & 67 & 73,63 & 81 & & \\
\hline Defisiensi besi & & & & & & & $0,001^{* *}$ \\
\hline $\mathrm{Ya}$ & 20 & 17,54 & 13 & 11,40 & 33 & $7,363(2,978-18,203)$ & \\
\hline Tidak & 14 & 12,28 & 67 & 58,78 & 81 & & \\
\hline Anemia defisiensi besi & & & & & & & $0,001^{* *}$ \\
\hline Ya & 19 & 16,96 & 12 & 10,72 & 31 & $7,577(3,418-22,150)$ & \\
\hline Tidak & 14 & 12,50 & 67 & 59,82 & 81 & & \\
\hline
\end{tabular}

${ }^{*}$ Uji Fisher, ${ }^{* *}$ Uji Kai Kuadrat

Tabel 3. Hubungan status besi dengan masalah perilaku internalisasi

\begin{tabular}{|c|c|c|c|c|c|c|c|}
\hline \multirow{2}{*}{ Status besi } & \multicolumn{4}{|c|}{ Perilaku internalisasi } & \multirow{2}{*}{ Jumlah } & \multirow{2}{*}{$\begin{array}{c}\text { OR } \\
(\mathrm{IK} 95 \%)\end{array}$} & \multirow{2}{*}{$\mathrm{p}$} \\
\hline & $\mathrm{Ya}$ & $\%$ & Tidak & $\%$ & & & \\
\hline Deplesi besi & & & & & & $1,175(0,129-10,671)$ & $0,622^{*}$ \\
\hline $\mathrm{Ya}$ & 1 & 1,09 & 9 & 9,90 & 10 & & \\
\hline Tidak & 7 & 7,69 & 74 & 81,32 & 81 & & \\
\hline Defisiensi besi & & & & & & $7,604(2,462-18,363)$ & $0,001^{* *}$ \\
\hline $\mathrm{Ya}$ & 15 & 13,16 & 18 & 15,79 & 33 & & \\
\hline Tidak & 8 & 7,02 & 73 & 64,03 & 81 & & \\
\hline Anemia defisiensi besi & & & & & & $8,706(13,049-24,861)$ & \\
\hline Ya & 14 & 12,50 & 17 & 15,18 & 31 & & $0,001^{* *}$ \\
\hline Tidak & 7 & 6,25 & 74 & 66,07 & 81 & & \\
\hline
\end{tabular}

${ }^{*}$ Uji Fisher, ${ }^{* *}$ Uji Kai Kuadrat 
dengan nilai Odds Ratio 8,706. Tidak dijumpai hubungan yang bermakna antara defisiensi besi dengan perilaku eksternalisasi $(\mathrm{p}=0,481)$, perhatian $(\mathrm{p}=0,329)$, dan campuran ( $\mathrm{p}=0,453)$.

Pada tabel 4 akan diperlihatkan beberapa faktor yang dapat mengakibatkan terjadinya masalah perilaku. Pada analisis bivariat didapatkan faktor yang mungkin berpengaruh terhadap perilaku anak usia 6-12 tahun yaitu status gizi, pendidikan ayah, status ekonomi, sifat ayah, dan defisiensi besi $(\mathrm{p}<0,250)$.

Tabel 4. Faktor-faktor yang berpengaruh terhadap perilaku $(\mathrm{n}=124)$

\begin{tabular}{|c|c|c|c|c|}
\hline & \multicolumn{2}{|c|}{ Masalah perilaku } & \multirow{2}{*}{$\begin{array}{c}\text { OR } \\
(\mathrm{IK} 95 \%)\end{array}$} & \multirow{2}{*}{$\mathrm{p}$} \\
\hline & $\mathrm{Ya}$ & Tidak & & \\
\hline \multicolumn{5}{|l|}{ Jenis kelamin } \\
\hline Laki-laki & 21 & 54 & 0,881 & \multirow{2}{*}{0,454} \\
\hline Perempuan & 15 & 34 & $(0,400-1,941)$ & \\
\hline \multicolumn{5}{|l|}{ Status gizi } \\
\hline Kurang & 7 & 26 & 1,737 & \multirow[t]{2}{*}{$0,176^{*}$} \\
\hline Baik & 29 & 62 & $(0,676-4,465)$ & \\
\hline \multicolumn{5}{|l|}{ Pendidikan ayah } \\
\hline Rendah & 21 & 42 & \multirow{3}{*}{$\begin{array}{c}1,769 \\
(0,796-3,930)\end{array}$} & \multirow{3}{*}{$0,113^{*}$} \\
\hline Menengah & 14 & 41 & & \\
\hline Tinggi & 1 & 5 & & \\
\hline \multicolumn{5}{|l|}{ Pendidikan ibu } \\
\hline Rendah & 15 & 41 & 0,819 & \multirow{3}{*}{0,383} \\
\hline Menengah & 19 & 43 & $(0,374-1,793)$ & \\
\hline Tinggi & 2 & 4 & & \\
\hline \multicolumn{5}{|l|}{ Status ekonomi } \\
\hline Rendah & 21 & 43 & 1,465 & \multirow[t]{2}{*}{0,224} \\
\hline Tinggi & 15 & 45 & $(0,669-3,207)$ & \\
\hline \multicolumn{5}{|l|}{ Status perkawinan } \\
\hline Cerai & 7 & 7 & 1,683 & \multirow[t]{2}{*}{0,262} \\
\hline Menikah & 41 & 69 & $(0,551-5,141)$ & \\
\hline \multicolumn{5}{|l|}{ Pengasuh } \\
\hline Selain orang tua & 5 & 5 & 1,651 & \multirow[t]{2}{*}{0,329} \\
\hline Orang tua & 43 & 71 & $(0,452-6,035)$ & \\
\hline \multicolumn{5}{|c|}{ Perlakuan kepada anak } \\
\hline Dimanja & 37 & 62 & 0,760 & \multirow{2}{*}{0,350} \\
\hline Biasa saja & 11 & 14 & $(0,312-1,847)$ & \\
\hline \multicolumn{5}{|l|}{ Sifat ayah } \\
\hline Biasa & 8 & 16 & & \multirow{3}{*}{$0,117^{*}$} \\
\hline Penyabar & 21 & 39 & $\begin{array}{c}1, / 16 \\
(0797-3693)\end{array}$ & \\
\hline Pemarah & 19 & 21 & $(0, / 91-3,093)$ & \\
\hline \multicolumn{5}{|l|}{ Sifat ibu } \\
\hline Biasa & 11 & 23 & 1,404 & \multirow{3}{*}{0,315} \\
\hline Penyabar & 27 & 41 & $(0,554-3,558)$ & \\
\hline Pemarah & 10 & 12 & & \\
\hline \multicolumn{5}{|l|}{ Lingkungan } \\
\hline Cukup & 16 & 26 & 1,040 & \multirow{2}{*}{0,539} \\
\hline Baik & 32 & 50 & $(0,484-2,234)$ & \\
\hline Defisiensi besi & & & & \\
\hline $\mathrm{Ya}$ & 20 & 13 & 7,212 & $0,001^{*}$ \\
\hline Tidak & 16 & 75 & $(2,984-17,431)$ & \\
\hline
\end{tabular}

Uji $\mathrm{x}^{2}, \mathrm{OR}=$ Odds Ratio, $\mathrm{IK}=$ interval kepercayaan, $\mathrm{p}<0,250$ 
Selanjutnya, untuk melihat faktor yang paling berpengaruh terhadap perilaku dan kekuatan hubungannya dilakukan analisis multivariat dengan regresi logistik menggunakan metode Backward dengan Likehood Ratio. Analisis multivariat faktor terhadap perilaku anak tertera pada Tabel 5. faktor yang paling berpengaruh terhadap perilaku anak usia 6-12 tahun adalah faktor defisiensi besi $(\mathrm{p}=0,001$ dan $\mathrm{OR}=6,901$. penelitian.

Berdasarkan interpretasi dari PSC-17 didapatkan sebagian besar anak yang mengalami masalah perilaku tergolong internalisasi. Hal tersebut sejalan dengan penelitian Harahap dkk $^{17}$ bahwa sebagian besar masalah perilaku yang dijumpai adalah internalisasi. Yudianita $\mathrm{dkk}^{16}$ juga melaporkan gangguan perilaku terbanyak adalah perilaku internalisasi. Namun, hasil tersebut berbeda dengan laporan Saragih $\mathrm{dkk}^{12}$

Tabel 5. Faktor yang paling berpengaruh terhadap perilaku anak

\begin{tabular}{lccccc}
\hline & $\mathrm{B}$ & $\operatorname{Exp}(\mathrm{B})$ & $\mathrm{p}$ & \multicolumn{2}{c}{ IK95\% } \\
\cline { 5 - 6 } & & & & Lower & Upper \\
\hline Status gizi & 0,622 & 1,863 & 0,249 & 0,647 & 5,368 \\
Pendidikan ayah & 0,359 & 1,432 & 0,444 & 0,571 & 3,589 \\
Status ekonomi & 0,213 & 1,237 & 0,653 & 0,489 & 3,113 \\
Sifat ayah & 0,451 & 1,569 & 0,265 & 0,865 & 4,582 \\
Defisiensi besi & 1,932 & 6,901 & 0,001 & 2,816 & 16,914 \\
\hline
\end{tabular}

Regresi logistik: $\mathrm{B}=\mathrm{OR}$ unadjusted; $\operatorname{Exp}(\mathrm{B})=\mathrm{OR}$ adjusted; $\mathrm{IK}=$ Interval kepercayaan

\section{Pembahasan}

Defisiensi besi merupakan salah satu masalah yang besar di bidang kesehatan. Karena angka kejadian defisiensi besi yang tinggi dan adanya dampak merugikan bagi pertumbuhan dan perkembangan anak, dibutuhkan deteksi dan intervensi dini terhadap defisiensi besi. Salah satu aspek perkembangan anak yang cukup terpengaruh, pada keadaan defisiensi besi, adalah masalah perilaku. Oleh karena itu, banyak penelitian yang berfokus pada hubungan perilaku anak dan defisiensi besi.

Data penelitian mendapatkan $25 \%$ prevalensi anemia defisiensi besi dan 26,6\% kejadian defisiensi besi pada anak usia sekolah di Kota Palembang. Berdasarkan interpretasi PSC-17, pada 124 subjek penelitian, terdapat 36 (29\%) anak dengan masalah perilaku. Berdasarkan The individuals with disabilities education improvement act (IDEA), prevalensi gangguan perilaku berkisar 3\%-6\% untuk anak prasekolah dan 5\%-15\% pada anak usia sekolah. ${ }^{15}$ Yudianita $\mathrm{dkk}^{16}$ mendapatkan prevalensi gangguan perilaku 15,1\% pada anak prasekolah di Kota Palembang. Penelitian ini menunjukkan prevalensi yang cukup tinggi dikarenakan usia subjek yang diambil berbeda. Sementara itu, ini, usia subjek penelitian ini 6-12 tahun, sedangkan penelitian Yudianita pada usia prasekolah. Selain itu, terdapat perbedaan karakteristik sosiodemografi subjek yang menjumpai masalah perilaku eksternalisasi dan internalisasi. Adanya perbedaan sosiokultural dan demografi pada kedua tempat dilakukannya penelitian mungkin menyebabkan perbedaan temuan ini.

Ditemukan adanya hubungan defisiensi besi dengan masalah perilaku maupun anemia defisiensi besi dan masalah perilaku. Hal ini menandakan, pada keadaan defisiensi besi tanpa ataupun adanya anemia telah menunjukkan adanya masalah perilaku pada anak usia sekolah. Hasil ini sejalan dengan laporan Lozoff $\mathrm{dkk}^{10}$ bahwa pada anak usia 11-14 tahun dengan defisiensi besi lebih banyak dijumpai gangguan perilaku dibandingkan anak tanpa defisiensi besi.

Masalah perilaku internalisasi merupakan masalah perilaku yang paling banyak ditemukan dan terdapat hubungan antara masalah perilaku internalisasi dengan defisiensi besi maupun anemia defisiensi besi. Pada sisi lain, tidak ditemukan hubungan antara defisiensi besi dengan masalah perilaku eksternalisasi, perhatian, dan campuran. Menurut Lozoff $\mathrm{dkk},{ }^{10}$ anak dengan defisiensi besi menunjukkan kelainan perilaku eksternalisasi dan internalisasi dibandingkan anak tanpa defisiensi besi. Temuan tersebut sedikit berbeda karena dominasi perilaku internalisasi yang lebih banyak muncul pada penelitian ini memiliki defisiensi besi. Perbedaan ini mungkin dikarenakan adanya perbedaan sosiodemografi, sosiokultural, dan genetik pada subjek penelitian tersebut. ${ }^{12}$ Adanya 
kecenderungan perubahan perilaku internalisasi dapat dijelaskan karena defisiensi besi memengaruhi reseptor D2 pada sistem dopaminergik yang lebih memengaruhi perilaku internalisasi. Pengaruh defisiensi besi pada reseptor D2 mengakibatkan sistem aktivasi dan inhibisi perilaku internalisasi terganggu sehingga terjadi perubahan persepsi, memori, dan motivasi yang berdampak terhadap tingkah laku. ${ }^{6} \mathrm{Pada}$ keadaan anemia, penurunan kadar hemoglobin akan menyebabkan manifestasi klinis berupa pucat, lemah, lesu, kurangnya konsentrasi, menurunnya aktivitas dan fungsi kognisi. Dengan demikian, masalah perilaku internalisasi tidak hanya dikarenakan karena adanya pengaruh besi pada sistem dopaminergik, tetapi juga diperburuk dengan adanya anemia. ${ }^{5}$

Banyak faktor yang dapat memengaruhi perilaku anak usia sekolah, antara lain jenis kelamin, status gizi, pendidikan orang tua, status ekonomi, status pernikahan keluarga, pengasuh dan pola perlakuan kepada anak, kondisi lingkungan, sifat ayah dan ibu, serta anemia defisiensi besi. ${ }^{10}$ Faktor yang mungkin berpengaruh-setelah dilakukan analisis bivariat-adalah status gizi, pendidikan ayah, status ekonomi, sifat ayah, dan anemia defisiensi besi.

Pada analisis multivariat digunakan regresi logistik. Faktor yang didapatkan paling berpengaruh terhadap perilaku anak usia 6-12 tahun di Kota Palembang adalah defisiensi besi. Sebaliknya, faktor lain-status gizi, pendidikan ayah, dan status ekonomi-setelah dilakukan regresi logistik tidak memiliki pengaruh terhadap perilaku.

Kekuatan dari penelitian ini adalah pemeriksaan laboratorium yang digunakan untuk menegakkan diagnosis defisiensi besi pada komunitas cukup lengkap. Selain itu, penilaian perilaku (PSC-17) dilakukan melalui wawancara terhadap orang tua dan wali kelas secara langsung sehingga informasi didapat dari dua sudut pandang yang menghasilkan penilaian yang lebih konsisten. Diharapkan dengan pemeriksaan tersebut, bias dapat diminimalisasi dan ketepatan hasil penelitian dapat ditingkatkan.

Jumlah sampel yang tidak besar menjadi keterbatasan dalam penelitian ini-validitas penelitian dapat ditingkatkan dengan sampel yang lebih besar. Selain itu, tidak ditelusuri pengaruh terapi besi terhadap perbaikan masalah perilaku.

\section{Kesimpulan}

Defisiensi besi merupakan faktor risiko untuk terjadinya masalah perilaku, terutama masalah perilaku internalisasi

\section{Daftar pustaka}

1. WHO. Cause of iron deficiency. Dalam: Preventing iron deficiency in women and children: tehnical consensus on key issues. New York:WHO;1999.

2. Clark SF. Iron deficiency anemia. Nutr Clin Pract 2008;23:128-41.

3. Soedjatmiko, Sekartini R, penyunting. Anemia pada anak sekolah di 11 propinsi di Indonesia. Jakarta:IDAI;2003.

4. Riset Kesehatan Dasar (RISKESDAS). Badan Penelitian dan Pengembang Kesehatan. Departemen Kesehatan Republik Indonesia. Riskesdas. Jakarta:Depkes RI; 2007.

5. Raspati H, Reniarti L, Susanah S. Anemia defisiensi besi. Dalam: Permono B, Sutaryo, Ugrasena IDG, Windiastuti E, Abdulsalam M, penyunting. Buku Ajar Hematologi Onkologi Anak. Edisi Pertama. Jakarta: Badan Penerbit IDAI;2005.h.30-43.

6. Beard JL. Iron deficiency alters brain development and functioning. J Nutr 2003;133:1468-72.

7. Nyayu Fatimah DM, Rismarini. Pengaruh defisiensi besi terhadap cognitive intelligence anak sekolah dasar di Kota Palembang (tesis). Palembang: Fakultas Kedokteran Universitas Sriwijaya, 2008.

8. Pollitt E. Iron deficiency and cognitive function. Am J Clin Nutr 1993;13:521-37.

9. Soemantri AG, Pollitt E, Kim I. Iron deficiency anemia and educational achiement. Am J Clin Nutr 1985;42:1221-28.

10. Lozoff B, Jimenez E, Hagen J, Mollen E. Poorer behavioral and developmental outcome more than 10 years after treatment for iron deficiency in infancy. Pediatrics 2000;105:e51-61.

11. Mubarak A, Fadel W, Said S, Hammar MA. Profile behavior and IQ in anemic children. CNS Spectrum 2010;15:1-6.

12. Saragih RAC, Zulaicha TM, Sofyani S, Lubis B, Lubis IZ. Behavior of elementary school children with iron deficiency anemia after iron therapy. Paediatr Indones 2009; 49:276-81.

13. Soedjatmiko. Skrining gangguan perkembangan perilaku anak dengan pediatric symptomp checklist. Pediatric Update 2005. Pendidikan Kedokteran Berkelanjutan Jakarta: IDAI Jaya;2005.h.53-8. 
14. Wu AC, Lesperance L, Bernstein H. Screening for iron deficiency. Hematology 2002; 23:171-7.

15. Peter WD, Wright E. The individuals with disabilities education improvement act (IDEA), 2004. Diakses tanggal 2 Februari 2015. Didapat dari: www.wrightslaw. com/idealidea.2004.all.pdf

16. Yudianita K, Rismarini. Hubungan gangguan bahasa dengan gangguan perilaku pada anak prasekolah di kota Palembang (tesis). Palembang: Fakultas Kedokteran
Universitas Sriwijaya, 2009.

17. Harahap DF, Sjarif DR, Soedjatmiko, Widodo DP, Tedjasaputra MS. Identification of emotional and behavior problems in obese children using child behavior checklist (CBCL) and 17-items pediatric symptom checklist (PSC-17). Paediatr Indones 2010;50:42-8. 